\title{
THE GAINS AND LOSSES OF CORRECTIVE JUSTICE
}

\author{
ERNEST J. WEINRIB†
}

\section{The Problem of Gain And Loss}

In Aristotle's classic account, corrective justice eliminates wrongful gains and their correlative losses. ${ }^{1}$ The question I address in this Essay is, what is the nature of these gains and losses?

According to Aristotle, liability is the law's response to an unjust gain by the defendant that is correlative to the plaintiff's unjust loss. Because the unjust transaction has caused the defendant to gain what the plaintiff has lost, corrective justice links the parties in a bipolar relationship that mirrors the bipolarity of the wrong being corrected. Thus, the correlativity of gain and loss accounts for the nexus between a particular defendant and a particular plaintiff.

Nevertheless, even sympathetic readers of Aristotle's text are often puzzled by his reference to correlative gain and loss. ${ }^{2}$ Aris-

t An earlier version of this Essay was presented at the Duke University School of Law as the Annual Brainerd Currie Memorial Lecture on March 18, 1994. I would like to thank Dean Pamela B. Gann and the faculty and students at the Duke University School of Law for their hospitality. I am particularly grateful to Martin Stone for his comments after the lecture.

Portions of this article are drawn from the forthcoming book, THE IDEA OF PRIVATE LAW by Emest Weinrib, to be published by Harvard University Press in 1995. Copyright 01995 in such portions held by the President and Fellows of Harvard College. Reprinted by permission of Harvard University Press. Copyright (c) 1994 in the remainder held by Ernest Weinrib.

1. ARISTOTLE, NicomacheAN EtHics V.4.1131b25-1132b20 (Ingram Bywater ed., 1894). Translations of Aristotle in this Essay are by the author.

2. Two recent examples are George P. Fletcher, Corrective Justice for Moderns, 106 HARV. L. REV. 1658, 1668 (1993) (reviewing JUlEs COLEMAN, RISKS AND WRONGS (1992) and noting that injury and gain may be in disequilibrium in "risk-taking" situations), and Stephen R. Perry, The Moral Foundations of Tort Law, 77 IOWA L. REv. 449, 457 (1992) (arguing that Aristotle's claim "does not seem to apply where the gainer's gain is not equal to the loser's loss"). 
totle seems to require that the gainer's unjust gain be equivalent to the loser's unjust loss. Only property takings clearly conform to this requirement. In contrast, most tort cases involving accidental harms feature a loss by the plaintiff from which the defendant realizes no corresponding gain.

Though this difficulty of corrective justice is usually raised in the tort context, it has wider application. Just as tort law compensates for losses that are unaccompanied by a correlative gain, so the law of unjust enrichment can require the restitution of gains by the defendant that are unaccompanied by losses to the plaintiff. ${ }^{3}$ In such cases, the very term "restitution" seems problematic, because the law grants plaintiffs what they never lost. ${ }^{4}$ These cases too, it would seem, fall outside the ambit of corrective justice.

The apparent vulnerability, on both sides, of the notion of correlative gain and loss casts doubt on the comprehensiveness of Aristotle's conception of corrective justice. Aristotle treats the correlativity of gain and loss as the organizing idea for the liability of defendant to plaintiff. Yet that idea seems inapplicable to wide swaths of modern private law. Consequently, the difficulty of including accidental losses has prompted the call for a "corrective justice for moderns." This new corrective justice in fact turns out to be a form of distributive justice and thus is categorically different from corrective justice as Aristotle understood it. ${ }^{6}$ "Corrective justice for moderns" continues Aristotle's terminology, but abandons his idea.

In this Essay, in contrast, I hold on to Aristotle's idea while recasting the termmology of gain and loss. As I have written elsewhere, Aristotle's idea of corrective justice is indispensable to understanding private law as a coherent normative practice.? Aristotle's specific terminology, however, stands on a different footing. Aristotle wrote at the dawn of legal philosophy, for a society with a less-developed private law than our own. It is not surprising, therefore, that better terms, drawn from subsequent

er's gain is not equal to the loser's loss").

3. Some of the better-known cases of this sort are mentioned infra Part VI.

4. Lionel D. Smith, The Province of the Law of Restitution, 71 CANAdian B. REv. 672 , 694-99 (1992) (suggesting that "disgorgement" rather than "restitution" is the appropriate term to describe the law's response to unjust enrichment through wrongdoing).

5. Fletcher, supra note 2, at 1658.

6. Id. at 1668 .

7. Ernest J. Weinrib, Corrective Justice, 77 Iowa L. REv. 403, 425 (1992). 
thinking about private law, are now available. Indeed, I shall argue that Aristotle's correlativity of gain and loss refers to the correlativity of right and duty, an idea that we have inherited from Kantian remterpretation of Aristotle's origmal notion.

Aristotle, I believe, would not be averse to such terminological recasting. This is evident from his comment about the very difficulty that bothers contemporary scholars. After remarking that the judge takes away the wrongdoer's gain, Aristotle observes,

"Gain" is what it is generally called in such cases, even though in certain cases it is not the appropriate term, for instance, for one who struck another-and "loss" for the one who suffered-but when the suffering is measured, it is called a loss for one party and a gain for the other. ${ }^{8}$

In this passage, Aristotle treats the assaulter's lack of material gain as nothing more than a terminological problein that does not greatly trouble him. Instead of excluding assaults from corrective justice, he merely affirms that "gain" is what the outcome for the defendant is generally called, however inappropriately. He then cryptically indicates that the plaintiff's loss is identical to the defendant's gam.

My comments in this Essay can be regarded as amplifying Aristotle's observation that "when the suffering is measured, it is called a loss for one party and a gain for the other." Aristotle is pointing here to some notional equivalence of gain and loss that obtains even if commission of the wrong has not materially enriched the wrongdoer. My task is to explicate this notional equivalence.

Despite my focus on Aristotle's text, I conceive this task as pliilosophical rather than exegetical. My aim is not to draw conclusions from Aristotle's words, let alone to reconstruct his mental processes, but to follow through on the conceptual implications of his account. Aristotle's exposition of corrective justice presents a series of ideas about the internal structure of what we now know as private law. I propose to explore the interconnections among these ideas, to illuminate them through the philosophical tradition of corrective justice, and to relate them to familiar features of private law.

8. ARISTOTLE, supra note 1 , at V.4.1132a10-14.

9. Id. 
Accordingly, this Essay has the following shape. After outlining the role of correlativity in Aristotle's treatinent of corrective justice, I distinguish between two conceptions of gain and loss-the material and the normative. I argue that Aristotle's reinarks on correlativity refer only to normative gains and losses. The terminology of gain and loss, as Aristotle himself tells us, reflects not a condition for hability, but the quantification of damages at the remedial stage. I then contend that Aristotle's notion of correlativity must be understood as referring to the Kantian rights and correlative duties that govern the interactions of free agents. Finally, I indicate how these conclusions about correlativity resolve the difficulty of lack of gain in tort cases, as well as the parallel difficulty of lack of loss in unjust enrichment cases.

\section{THE Role of CORRELATIVITY}

Aristotle describes corrective justice as follows. Corrective justice deals with the relationship of the doer and the sufferer of a wrong. From the standpoint of corrective justice, the two parties are equals, and justice consists in vindicating their equality. The doer's unjust treatment of the sufferer disturbs this equality, leaving the doer with a gain and the sufferer with an equivalent loss. To reestablish the initial equahty, corrective justice requires the doer to repair the loss by returning the gain to the sufferer. Thus, a single operation ehminates both gain and loss. Aristotle compares the position of the two parties to lines of equal length. ${ }^{10}$ The injustice consists in attaching to the doer's line a segment of the sufferer's, thereby producing an inequality that is twice the length of the segment. The judge restores the equality by removing the segment from the doer's line and reattaching it to the sufferer's.

Aristotle's account makes salient the interdependence of the two parties under corrective justice. Corrective justice does not view the gain and the loss as discrete phenomena that happen to coincide. The sufferer loses by virtue of the doer's gain, and vice versa. Gain and loss are correlatives because each is constituted by the other. Similarly, the judge's reestablishment of the parties' equality does not consist of two independent operations, one of which removes the gain and the other of which repairs the loss.

10. Id. at V.4.1132b6. 
The doer is directly liable to the sufferer, so that reparation of the loss occurs through disgorgement of the gain.

By directly linking the parties, corrective justice categorically differs from distributive justice, the other form of justice that Aristotle describes. ${ }^{11}$ Distributive justice involves slaring a benefit or burden in accordance witl some criterion. Instead of linking one particular party to anotlier as doer to sufferer, distributive justice links all parties to the benefit or burden in which they sliare. Accordingly, distributive justice differs from corrective justice by not being restricted to two parties. Whereas the addition of parties im corrective justice is inconsistent with its structure, the addition of parties in distributive justice merely decreases each person's sliare of what is distributed.

Two important points are implicit in Aristotle's account of corrective justice. The first concerns the connection between the two particular parties. In considering liability, we might wonder, why is the victim of harm entitled to recover from this particular defendant, rather than from someone more evil or more capable of bearing the expense of liability? Similarly, why is the defendant liable to this particular sufferer rather than to someone more needy or more virtuous? Formulated negatively, i.e., as why these others cannot sue or be sued, the answer is that considerations like wealth, need, and character provide no ground for connecting individual litigants. Even on the assumption tliat redistribution is desirable, a potential defendant's cliaracter and financial resources are not reasons for making a particular plaintiff (as opposed to others in need) the beneficiary of that person's wealth. Similarly, the plaintiff's need and virtue are not reasons for requiring anything of this particular defendant, rather than of others who are similarly situated. ${ }^{12}$

Aristotle treats the correlativity of the defendant's gain to the plaintiff's loss as the positive reason for connecting the two particular parties. Because correlativity links two and only two terms, it provides a reason for connecting two parties to the exclusion of everyone else. Under corrective justice, liability is the juridical manifestation of the logic of correlativity.

11. Id. at V.4.1131a10-b24.

12. Such operations belong to distributive justice, which apportions benefits and bur- dens among everyone who ought to participate in their distribution. 
The second point deals with the nature of adjudication. Under corrective justice, rectification responds to the injustice being rectified. The court's action is the reflex of the wrong, not the commencement of a new juridical sequence. Judges cannot, therefore, view the wrongdoing as a sunk cost that leaves them with the task of determining, all things considered, what is best for society. The sole function of the judge- "justice ensouled," in Aristotle's graphic phrase ${ }^{13}$-is to undo the injustice of the correlative gain and loss. The structure of correlativity that characterizes the injustice necessarily characterizes the rectification that reverses that injustice.

The problem of gain without apparent loss (and vice versa) arises at the conjunction of these two points. The mirroring of injustice through rectification means that the payinent of dainages by the defendant restores the loss that the plaintiff suffered through being wronged. The connection between the parties requires that this loss by the plaintiff be correlative to a gain by the defendant. But then how does corrective justice include tort cases in which the wrong does not benefit the defendant and restitution cases in which the plaintiff does not lose through the defendant's unjust enrichment?

\section{Two Conceptions of GAIN AND Loss}

To answer this question, we must deterınine more precisely what Aristotle means by gain and loss. These words signify excess and shortfall relative to some baseline. What is the baseline?

One possibility is that gain and loss are variants from each litigant's antecedent resources. We may call this the "material" conception of gain and loss, because it focuses on the extent to which the hitigant is naterially better or worse off than before the wrong. The inaterial conception of gain and loss refers to the effect of the interaction on the amount or condition of one's resources (broadly construed to include both one's body and the external objects at one's disposal). In its material aspect, a gain is an increase in a party's resources; a loss is a decrease.

A second possibility is what we may call the "normative" conception of gain and loss. Under this conception, gains and losses refer to discrepancies between what the parties have and

13. ARISTOTLE, supra note 1 , at V.4.1132a22. 
what they should have according to the norm governing their interaction. The baseline for normative gains and losses is one's due under the relevant norm. A gain is an excess over, and a loss a shortfall from, one's due.

Suppose, for example, that you negligently mjure me. A comparison of my present and previous conditions reveals that I am inaterially worse off than I was before. This is the material conception of the loss. In addition, however, I am also worse off than I should be, given the norm against negligent injuring. ${ }^{14}$ The loss considered from the standpoint of this norm falls under the normative conception. The material and the normative conceptions are both present in this example, because the negligent injury that makes me materially worse off than I was before is also the injury that I should not have suffered, given the norm against neghigence. They are, however, analytically distinguishable: if you mjure me nontortiously, the loss I suffer falls under the material conception, but because you have breached no norm, the normative conception of loss is inapplicable.

The distinction between material and normative gains and losses allows the possibility that a gain or loss of one type may be unaccompanied by a gam or loss of the other. All the possible coinbimations are recognized in sophisticated systems of private law. A party may realize (1) a normative gain but no material gain: if I neghigently injure anotler, I am liable for my wrongdoing, but my resources have not been increased by the wrong; (2) a material gain but no normative gain: if another mistakenly paves my driveway witlout my knowledge, my resources have been increased, but I owe the improver nothing; (3) a normative loss, but no material loss: if someone trespasses on my property without impairing its condition, a common law court may award me nominal damages to mark the breach of a norm, despite the absence of material loss; or (4) a inaterial loss, but no normative loss: if someone injures me without fault, I generally cannot recover despite the impairment of my physical condition.

Given the two conceptions of gain and loss, what precisely lias to be correlative to what if there is to be liability under corrective justice? The logic of correlativity requires that what is predicated

14. Conversely, as the tortfeasor, you have more than you ought to have, given that you have breached the norm against negligent injuring. Liability forces you to surrender this excess over your due. 
of one element in the pairing also be predicated of the other. ${ }^{15}$ Accordingly, the gains and losses must be of the same kind. We can, therefore, eliminate the possibility of a material loss correlative to a normative gam or of a material gain correlative to a normative loss. We are then left with the question of whether corrective justice features a correlativity of material gain to material loss, or of normative gain to normative loss.

The first of these alternatives can be readily eliminated, because the correlativity of exclusively material gains and losses makes no sense. We cannot tell what constitutes a material gain or loss for purposes of corrective justice until we situate gain and loss within a normative framework. The problem is that while material loss operates from the baseline of one's antecedent resources, the connection between resources and the person holding them has an unavoidably normative dimension. Resources are "mine" only if I hold them legitimately, and legitimacy entails the operation of a legitimating norm. Changes in resources can function as the basis of rectification only once the normative connection between resources and claimants is settled, and then the gains and losses are no longer exclusively material ones. ${ }^{16}$

In particular, unless we determine whether and under what conditions the freedom to act (or to abstain from acting) is included among the resources of potential defendants, corrective justice cannot work at all. This is clear in situations of nonfeasance, in which the failure to act allows the materialization of an independently arising risk of harm. In such cases, a regime of exclusively material gain and loss is unable to determine whether the consequent injury is a material loss caused by the failure to act or whether the freedom to abstain from acting is itself an entitlement whose exercise does not infringe corrective justice. The same applies to cases of misfeasance, for if the freedom to act is within

15.

Another topic is derived from correlatives. If to have done rightly or justly may be predicated of one, then to have suffered similarly may be predicated of the other. Similarly with ordering and executing an order. As Diomedon the taxcontractor said about the taxes, "If selling them is not disgraceful for you, buying them is not disgraceful for us." And if rightly or justly can be predicated of the sufferer, it can equally be predicated of the doer, and if of the doer, then also of the sufferer.

ARISTOTLE, RHETORIC II.23.1397a23-27 (W.D. Ross, ed. 1959).

16. Even in the case of a taking, in which the appropriator's gain is matcrially equivalent to the victim's loss, liability follows not from the equivalence, but from the breach of a property norm. 
the defendant's resources, the supposed injustice of injuring the plaintiff could be corrected only by fettering the defendant's freedoin, thus causing a new inaterial loss (this time to the defendant) that would itself be the grounds for a correction. Corrective justice would thereby become an endless series of injustices, in which each successive material loss would trigger another correction that itself would create a material loss. ${ }^{17}$

That Aristotle means the gains and losses of corrective justice to be normative is evident from his treating equality as their baseline. If material gains and losses were mvolved, the equality would liave to be material as well. Corrective justice would then require that the parties to any transaction have equal resources at the transaction's inception. Corrective justice would be unavailable to the victim of a tort, for instance, unless the victim and the tortfeasor liad equal resources when the tort was committed. Aristotle cannot be read as committed to so strange a conception. Equality of resources concerns the distribution of resources within society and is thus a matter for distributive, ratlier than corrective, justice. Since the categorical difference between corrective and distributive justice is theinatic in Aristotle's account, the former ouglit not to be subsumed under the latter by inaking the baseline for corrective justice itself a distributive notion. To put the same point in a different way, since corrective justice is the juridical expression of the logic of correlativity, the equality that serves as the baseline for the gains and losses of corrective justice must itself participate in that correlativity by applying to two parties and no more. Equality of resources fails because it can exist among any number of parties.

In Aristotle's account, equality is merely a formal representation of the norm that ought to obtain between doer and sufferer. Action that conforms to this norm, whatever it is for any transaction, maintains the equality between the parties, so that no complaimt is justified. Action that breaches this norm produces a gain to the injurer and a loss to the person injured; then the court

17. For a related criticism of Robert Nozick's use of the Lockean proviso, see Ernest J. Weinrib, Right and Advantage in Private Law, 10 CARDOzo L. REv. 1283, 1293-97 (1989); see also Perry's illuminating remarks about Coase's theorem, Perry, supra note 2, at 465 . A case whose orientation towards material loss brings it close to the regress presented here is Spur Industries v. Del E. Webb Development Co., 494 P.2d 700, 708 (Ariz. 1972), im which the defendant-tortfeasor succeeded in securing an entitlement to compensation for the loss it would suffer under the injunction awarded to the plaintiff. 
restores the parties to the equality that would have prevailed had the norm been observed. The normative nature of the equality indicates that the variations from that equality are also normative.

We can now see why the idea that corrective justice is inapplicable to the accidental injury is misguided. Underlying this idea is the obvious fact that such an injury does not produce a material gain for the tortfeasor, let alone a material gain that is equivalent to the victim's material loss. This fact, however, is irrelevant, because corrective justice is concerned with the correlativity of normative, not material, gain and loss.

In the Aristotelian account, the terms "gain" and "loss" are a way of representing the occurrence of the injustice that liability rectifies. What matters is whether the transaction can be regarded as yielding the defendant more and the plaimtiff less than the parties ought to have, given the norm that should have governed their interaction. ${ }^{18}$ In tort cases, therefore, liability for injuring the plaintiff is predicated not on some parallel increase in the defendant's resources, but on the defendant's having unjustly inflicted that loss. Similarly, in the case of unjust enrichment, the plaintiff recovers the defendant's gain not when the plaintiff has suffered a corresponding material loss, but when the defendant's enrichment represents an injustice to the plaintiff.

\section{The TERminology of "GaIN" AND "Loss"}

One might object that my argument so far shows only that corrective justice does not concern material gain and loss exclusive$l y$, but also concerns normative gain and loss. Perhaps corrective justice requires material gains and losses in addition to normative ones. Then hability would depend not only on the occurrence of a wrong but on the defendant's having materially gained-and the plaintiff's having materially lost-through the wrong. Otherwise, why did Aristotle invoke gain and loss at all in explaining the correlativity of corrective justice?

Supporting this objection is the fact that Aristotle's account of corrective justice presents two formulations of correlativity. One formulation refers to gam and loss, ${ }^{19}$ the other, to the doing and

18. Aquinas expressly observes that according to Aristotle "loss is called so from one having less than he should have." 37 ThOMAS Aquinas, SUMma THEOLogiaE II-II, question 62, art. 5, at 113 (Thomas Gilby trans., 1975).

19. ARISTOTLE, ETHICS, supra note 1, at V.4.1132a10, a16, b12. 
suffering of injustice. ${ }^{20}$ (Sometimes he even combines the two in a barely comprehensible jumble. ${ }^{21}$ ) Gain and loss, one might think, represent the correlativity in material terms, with the increase in the wrongdoer's resources being at the cost of a decrease in the victim's. The doing and suffering of injustice, on the other hand, inight represent the correlativity in normative terms, as the active and passive poles of one person's wronging another. These two formulations might be read as separate conditions for corrective justice, so that normative gain and loss alone are insufficient. The result would be that a tort through which the defendant does not materially gain and an unjust enrichment through which the plaimtiff does not materially lose would fall outside corrective justice.

Such a reading would be unsound. First, Aristotle has no reason to exclude such imjustices from what purports to be a comprehensive account of justice. Second, correlativity of inaterial gain and loss is conceptually superfluous. The essential feature of the ground of liabihty-what characterizes the bipolar claims under corrective justice and distinguishes them from the possible openendedness of distributive justice-is the correlativity that structures the parties' relationship. Such correlativity is fully satisfied when the defendant's action wrongs the plaintiff.

Aristotle's comment on the use of the terms "gain" and "loss" confirms that corrective justice does not require material correlativity:

"Gain" is what it is generally called in such cases, even though in certain cases it is not the appropriate term, for instance, for one who struck another-and "loss" for the one who suffered-but when the suffering is measured, it is called a loss for one party and a gain for the other. ${ }^{22}$

20. Id. at V.41132as ("If one has committed and the other has suffered injustice, and if one has harmed and the other been harmed."); id. at V.4.1132a8 ("When one has hit and the other been hit, and when one has killed and the other has been killed."). I believe that "harm" has a normative connotation, referring not merely to a physical event but to what is actionable, as is the case in Aristotle's listing of the three kinds of harm, id. at V.8.1135b10.

21. Id. at V.4.1132a8 ("The doing and the suffering have been unequally divided."). As $I$ hope the argument in this Part substantiates, the reason that Aristotle allows himself to combine these two formulations within a single clause is that he regards them as equivalent and therefore as interchangeable.

22. Id. at V.4.1132a10-14. 
Far from signifying a separate condition of liability, gain is simply what the suffering of injustice is "generally called ... when ... measured."23 Gain and loss are not additional to wrongdoing; rather, they are its quantified manifestations. Thus, Aristotle's text makes explicit what is implicit $\mathrm{m}$ his argunent: that wrong to the victim suffices for corrective justice in the absence of material gain by the wrongdoer.

Aristotle's observation about measurement alludes to the role of monetary damages in the rectification of wrongs. These damages translate the doing and suffering of wrong into quantitative terms. Once perpetrated, the wrong is no longer only the breach of the norm, the doing of an act that should not have been done; it is now also an injury that the defendant nuust undo to the extent possible. Througlh the notion of damages, this injury takes the form of soniething repayable: a monetary anount is debited against the defendant's moral account with the plaintiff, and the payment of this sum discharges the defendant's liability and wipes the ledger clean. Daniages inaintain the correlativity of the parties' positions by making the aniount that represents the doing of the wrong identical to the amount that represents the suffering of wrong. These amounts are the same because they quantify the same wrong. That is why "when the suffering is measured, it is called a loss for one party and a gain for the other."24

23. Id.

24. Id. Aristotle's comment is the earliest adumbration of the role of value in corrective justice. Value is the concept through which a qualitatively unique phenomenon (my particular injury, for example) receives the quantitative expression that permits it to function within a juridical relationship. The qualitative uniqueness of the injury figures only within the experience of the injured party. Value quantifies the injury, so that the injurer can discharge the liability generated by it. By thus connecting the parties at the remedial stage, value serves the same correlative function that the norm serves at the stage of conduct. On the role of value in corrective justice (or, as Hegel calls it, in "abstract right"), see GeORG W. FRIEDRICH HEGEL, PHILOSOPHY OF RIGHT I 98, at 69 (T. M. Knox trans., Oxford Uuiversity Press 1951) (1821); see also id. TI 63, 77, 101. Hegel characterizes value as "the mner equality of things which in their outward existence are specifically different ... in every way." Id. T 101, at 72 . On Aristotle's contribution to the theory of value, see Scott Meikle, Aristotle and the Political Economy of the Polis, 99 J. HELlENIC STUd. 57 (1979).

The use of value implies that for juridical purposes the injury is commensurable with monetary damages. No support, however, thereby accrues to economic analysis or to the idea that values are commodities. The quantification of a breached entitlement operates only remedially and does not affect the judgment that the injury was a wrong and that the defendant committed an injustice in causing it. But see Margaret J. Radin, Compensation and Commensurability, 43 DUKE L.J. 56, 64-66 (1993). Radin's suggestion that 
For Aristotle, then, the terms "gain" and "loss" have currency only because he reads them back into the relationship from its remedial stage. They are not conditions of liability. The absence of a material gain by the tortfeasor or of a material loss by the victim of unjust enrichment is, therefore, irrelevant. All that liability under corrective justice requires is that one person have wronged another. The gains and losses in Aristotle's text are nothing but quantitative representations of the doing and suffering of wrong. Properly understood, they refer to surpluses and shortfalls not from what the parties had before the unjust act, but from what the parties ought to have in view of the requirements of corrective justice.

\section{RIGHT AND DUTY}

I want now to indicate why the correlativity inherent in corrective justice corresponds to the Kantian conception of right and correlative duty. To see this, we inust focus on the reason for the norm that underhes normative gain and loss. Corrective justice presupposes some reason (or set of reasons) for regarding certain acts as wrongful and for rectifying their consequences. Nornative gains and losses are surpluses and shortfalls from what the parties should have when that reason, whatever it is, applies to their relationship. Normative gain (the condition of having more than one ought to) exists when that reason justifies decreasing the defendant's resources; normative loss (the condition of having less than one ought to) exists when that reason justifies increasing the plaintiff's.

Because corrective justice embodies correlativity, a reason that accords with corrective justice must apply equally to both parties. Application to only one of the parties could not account for the correlative effect on the other. A reason that applies only to the plaintiff yields a normative loss and thereby justifies augmenting the plaintiff's resources; it does not, however, justify decreasing the defendant's. And the converse is true for a reason that applies only to the defendant. However appealing such reasons might be, they are incapable of fitting within corrective justice.

commensurability fits only within economic analysis or utilitarianism is refuted by the example of Hegel. 
For example, the compensation rationale cannot be considered a reason for tort liability withm corrective justice. Since this rationale rests on the plamtiff's need in the aftermath of injury, it does not encompass the defendant. Thus, although injury might be thought of as a normative loss consisting in the shortfall from the plamtiff's entitlement under the compensation rationale, that rationale provides no ground for regarding the defendant as having unduly gained. At inost, the plaimtiff's need for compensation justifies improving the plaintiff's situation; it does not justify taking anything froin the defendant. Accordingly, the compensation rationale does not support the defendant's liability to the plaintiff.

Conversely, suppose that a reason for liabihity applies to the defendant but not to the plaintiff (for example, the deterrence rationale for tort liability). Such a reason might be grounds for penalizing the defendant. Plamtiffs who do not come within the reason's reach, however, cannot be said to have less than they are entitled to under it. In the light of such a reason the defendant may be said to have too inuch unless held liable, but the plaintiff cannot be said to have too little. Consequently, there is no reason for the defendaut's hability to the plaintiff.

Nor can correlativity be satisfied by a combination of reasons that einbrace both parties by applying separately to each of them. For example, one cannot justify tort liability by reference to the need both to deter actors and to compensate sufferers. To be sure, such a coinbination produces a normative gain for the defendant and a normative loss for the plaintiff. But because the reason for thinking the defendant to have gained is not the same as the reason for thinking the plaintiff to have lost, the gain and the loss are not normatively correlative. The combination of reasons may justify ehinmating the gain and the loss through separate operations that decrease the resources of the defendant and increase those of the plaintiff. However, it does not justify directly linking the parties through the hability of corrective justice.

In contrast to such one-sided reasons, Kant's legal theory presents reasons that are correlatively structured as right and duty. Kant's legal theory is a philosophy of freedom that starts with the operation of free will conceived as self-determining activity. ${ }^{25}$ The fundamental principle applicable to the interaction of self-deter1991).

25. ImManuel Kant, The Metaphysics of Morals $40-43$ (Mary Gregor trans., 
mining beings is that action should be consistent with the freedom of whomever the action might affect. ${ }^{26}$ Rights-imcluding those to physical integrity, ${ }^{27}$ property, ${ }^{28}$ and contractual performance ${ }^{29}$-are the juridical manifestations of the freedom inherent in self-determining activity. Action is therefore consistent with the freedorn of others when it is coinpatible with their rights. Having a right implies that other actors are under the moral necessity to refrain from infringing it. In Kant's words, rights are "moral capacities for putting others under obhigations.",30

The Kantian approach, then, links the imteracting parties through a right, on one hand, and a corresponding duty, on the other. The right represents the moral position of the plaintiff; the duty represents the moral position of the defendant. Right and duty-and therefore plaintiff and defendant-are colmected because the content of the right is the object of the duty. The Kantian principle that the action of one party should be consistent with the freedom of another is satisfied when the action of one party does not violate a duty, the freedom of the other manifests itself in a right, and free will grounds both the right and the duty and connects one to the other.

This conjunction of right and duty fulfills the requirement of correlativity within corrective justice. The plamtiff's suffering consists in an mjury to something to which the plaintiff has a right. The defendant's wrongdoing consists in the breach of a duty owed the plamtiff. The same reason applies to both defendant and plamtiff because the existence of the right is the reason for the existence of the duty. If the defendant, by breaching a duty owed to a third party, mjures something to which the plaintiff has a right, there is no hability under corrective justice, because in that case the duty breached is not correlative to the plaintiff's right. ${ }^{31}$ Similarly, if the defendant mjures something to which the plaintiff has

26. Kant's formulation of this principle is: "Any action is right if it can coexist with everyone's freedom in accordance with a universal law, or if on its maxim the freedom of choice of each can coexist with everyone's freedom in accordance with a universal law." Id. at 56. My simplification in the text is for purposes of exposition only.

27. Id. at 63 .

28. Id. at $82-90$.

29. Id. at $90-95,101-03$.

30. Id. at 63 (brackets and emphasis omitted).

31. "The plaintiff sues in her own right for a wrong personal to her, and not as the vicarious beneficiary of a breach of duty to another." Palsgraf v. Long Island R.R., 162 N.E. 99, 100 (N.Y. 1928). 
a right by breaching a duty regarding something else in which the plaintiff has a right, there is no liability under corrective justice. ${ }^{32}$

When the duty breached is correlative to the plaintiff's right, the saine reason is the basis of the defendant's normative gain and the plaintiff's normative loss. In the absence of liability, that reason is grounds for regarding the defendant as having too inuch and the plaintiff too little. As Aristotle reınarks, "[I]t is called a loss for one party and a gain for the other." ${ }^{33}$ Liability then applies the defendant's normative gain to the elimination of the plaintiff's normative loss. Because the normative gain and the normative loss are correlative aspects of the same wrong, the defendant's liability is identical with the plaintiff's entitlement to rectification. Hence private law is a system of direct claims by plaintiffs agamst defendants.

The parties' equality under corrective justice confirms the link between Aristotle's account and Kant's legal theory. Whereas Aristotle regards equality as the baseline for gam and loss, Kant's notion of self-determining agency supplies the meaning of that equality. As Aristotle limself notes, the parties to a corrective justice transaction are equal in a very peculiar way: the equality abstracts from the particularity of the parties' social rank or moral character to the slieer relationship of wrongdoer and sufferer. ${ }^{34}$ Corrective justice treats the parties as equals because all self-determining beings, regardless of rank or character, have equal moral status. The conjunction of riglit and duty is simply this equality of self-determining beings viewed juridically, from the standpoint of the correlativity of one person's action and its effects on another. $^{35}$

32. In this respect, RESTATEMENT OF TORTS § 281 (1934), which makes it a condition of liability for negligence that "the conduct of the actor is negligent with respect to such interest or any other similar interest of the other which is protected against unintentional invasion," is closer to corrective justice than RESTATEMENT (SECOND) OF TORTS § 281 (1965), which omits this clause. George C. Christie, CASES AND Materials on THE LAW OF TORTS 266 (2d ed. 1990).

33. ARISTOTLE, supra note 1, at V.4.1132a13.

34. "Whether a worthy person has taken from an unworthy person or vice versa makes no difference ... [;] the law treats them as equals if the one does and the other suffers injustice, and if the one does and the other suffers harm." Id. at V.4.1132a2-6.

35. For a more complete argument of the connection between corrective justice and Kantian right, see Weinrib, supra note 7, at 422-25; see also Peter Benson, The Basis of Corrective Justice and Its Relation to Distributive Justice, 77 IowA L. REv. 515, 601-24 (1992). But see Steven J. Heyman, Aristotle on Political Justice, 77 IOWA L. REv. 851, $860-63$ (1992). 
Aristotle's thinking antedates the evolution of rights as legal and theoretical concepts. Thus, instead of focusing on the correlativity of rights and duties, he describes corrective justice through the correlativity of gains and losses, while observing that "in certain cases gain is not the appropriate term. ${ }^{336}$ Whatever his terminology, he inust be understood as referring to what we now know as rights and duties. For if we ask why the court returns what the plaintiff has lost through the defendant's wrong, the only answer is that the plaintiff has a right to it. And if the plaintiff is entitled to the remedy, it must be-by Aristotle's own account of adjudication as a response to wrong - that the right to this remedy mirrors the right infringed through the defendant's wrongdoing.

\section{TORT LAW AND UNJUST ENRICHMENT}

I began by addressing the apparent discrepancy between corrective justice as a theoretical idea and private law as a faniliar practice. As a theoretical idea, corrective justice features the correlativity of gain and loss and thus seems to require that the gainer's gain be equivalent to the loser's loss. As a familiar practice, private law recognizes liability when the tortfeasor realizes no gain corresponding to the loser's loss and when the victim of unjust enrichment realizes no loss corresponding to the gainer's gain. My suggestion has been that once we understand that the gains and losses of corrective justice are normative rather than inaterial, the apparent difficulty dissolves.

Through the commission of a tort, the plaintiff suffers a norinative loss, and the defendant a correlative normative gain. The plaintiff's normative loss consists in the shortfall from what the plaintiff is entitled to under the norm that the defendant's action violated. Conversely, the defendant's normative gain consists in the excess over what the defendant ought to have, given the defendant's violation of the norm that the duty reflects. Reparation of the plaintiff's loss and removal of the defendant's gain are both justified by the defendant's having violated a duty not to infringe the plaintiff's right. Since normative gain and loss are correlative to each other, the valuation of the loss to be repaired also supphes the measure of the defendant's correlative normative gain. ${ }^{37}$

36. ARISTOTLE, supra note 1, at V.4.1132a11.

37. Under corrective justice, damages are compensatory, not punitive. Therefore, the 
As Aristotle remarks, "When the suffering is measured, it is called a loss for one party and a gain for the other." ${ }^{38}$ Thus, tort liability conforms to corrective justice even when the tortfeasor realizes no material benefit from the wrong.

Tort hability is a regime of right and correlative duty when it contains the following elements. ${ }^{39}$ First, to recover in tort, the plaintiff's mjury must be to something that ranks as the embodiment of a right, such as personal integrity or a proprietary entitlement. It is not sufficient that the plaintiff has suffered the merely material loss of being made worse off or of being deprived of a prospective advantage..$^{40}$ Second, the defendant must have com-

common law jurisdiction whose attitude regarding punitive damages comes closest to conformity to corrective justice is England, which, since Rookes v. Barnard, 1964 App. Cas. 1129, 1131 (H.L.), has restricted punitive damages to cases of oppressive, arbitrary, or unconstitutional governmental action, cases in which the defendant has calculated that the gain from misconduct will exceed the compensation payable to the plaintiff, and cases in which punitive damages are expressly authorized by statute. For a survey and discussion of different approaches to punitive damages, see generally Bruce Chapman \& Michael Trebilcock, Punitive Damages: Divergence in Search of a Rationale, 40 ALA. L. REV. 741 (1989).

38. ARISTOTLE, supra note 1, at V.4.1132a13.

39. I am claiming not that all instances of tort liability in any given jurisdiction conform to corrective justice, but only that they conform to corrective justice when they contain the elements that follow. There may well be instances of liability that do not contain these elements (indeed, I suggest some infra notes 40, 42). Such instances cannot count as corrective justice. Since I regard corrective justice as the structure for coherent private law doctrine, see supra text accompanying note 7. I would regard such instances of liability as demonstrably incoherent. My main point is that the absence of material gain by the wrongdoer is not what makes liability inconsistent with corrective justice.

40. For example, in Fontainebleau Hotel Corp. v. Forty-Five Twenty-Five, Inc., 114 So. 2d 357 (Fla. Dist. Ct. App. 1959), cert. denied, 117 So. 2d 842 (Fla. 1960), the plaintiff hotel sued its neighbor for building a structure that cast an afternoon shadow on its bathing area. In dismissing the action, the court remarked that the maxim sic utere tuo ut alienum non laedas "does not mean that one must never use his own property in such a way as to do any injury to his neighbor. . . . It means only that one must use his property so as not to injure the lawful rights of another." Id. at 359 (citations omitted). The same issue arises when the defendant causes economic loss by negligently interfering with some facility that is not owned by the plaintiff but is essential for the plaintiff's business. E.g., Caltex Oil v. The Dredge "Willemstad," 136 C.L.R. 529 (1976) (Austl.) (pipeline); Norsk Pacific Steamship Co. v. Canadian Nat'l R.R., [1992] 1 S.C.R. 1021 (Can.) (bridge); Spartan Steel \& Alloys Ltd. v. Martin \& Co. (Contractors), 1973 Q.B. 27 (Eng. C.A.) (power line); Cattle v. Stockton Waterworks Co., 10 L.R.-Q.B. 453 (1875) (tunnel). Historically, the common law denied recovery except to the extent that the economic loss was a quantification of the damage done to something that embodied the plaintiff's right. The economic loss standing on its own was insufficient for liability. The historic common law result is in accord with corrective justice. More recently, Commonwealth courts have experimented with allowing recovery as long as they feel that the claim can be limited through notions of proximity. See Caltex Oil, 136 C.L.R. at 555-56. See also the opinions 
mitted an act that violates a duty incumbent on the defendant and thus can be regarded as wrongdoing. Accordingly, modern common law emphasizes the importance of fault, since the defendant is duty-bound not to perform the intentional or negligent acts that constitute faulty conduct. ${ }^{41}$ Third, the duty breached by the defendant must be with respect to the embodiment of the right whose infringement is the ground of the plaintiff's cause of action. ${ }^{42}$

When the defendant thus breaches a duty correlative to the plaintiff's right, the plaintiff is entitled to reparation. The remedy reflects the fact that even after the commission of the tort, the defendant remains subject to the duty with respect to the plamtiff's right. The defendant's breach of the duty not to interfere with the embodiment of the plaintiff's right does not, of course, bring the duty to an end, for if it did, the duty would-absurdly-be discharged by its breach. Given the occurrence of wrongful injury, the only way the defendant can discharge his obligation with respect to the plaintiff is to undo the effects of the breach of duty. Just as the plaintiff's right constitutes the subject matter of the defendant's duty, so the wrongful interference with the right entails the duty to repair. Thus, tort law places the defendant under the obligation to restore the plaintiff, insofar as possible, to the position the plaintiff would have been in had the wrong not been committed.

These observations about tort hability apply, mutatis mutandis, to the law of unjust enrichment. As far as correlativity is concerned, the law of unjust enrichment is the mirror image of tort law. Whereas tort law allows recovery for material loss that is un-

favoring liability in Norsk Pacific Steamship Co., [1992] 1 S.C.R. at 1022-25. The problem of limiting recovery, however, presupposes that one has located (as these judgments have not) the entitlement with respect to which the recovery is to be limited.

41. Brown v. Kendall, 60 Mass. (6 Cush.) 292, 298 (1850).

42. See supra notes 31-32. Corrective justice allows one to understand why the doctrine of transferred intent, under which the defendant is held liable for harm done to one person as a result of an act performed with the intent to harm another, is indeed "something of a freak," as it is termed in WILliaM L. PROSSER ET AL., TORTS: CASES AND Materials 29 (7th ed. 1982). This doctrine, exemplified in Talmage v. Smith, 59 N.W. 656, 657 (Mich. 1894), in effect holds that there is liability even when the defendant's breach of duty is not correlative to the plaintiff's infringed right. The doctrine is discussed in William L. Prosser, Transferred Intent, 45 TEX. L. REv. 650 (1967). Prosser treats the doctrine as a curious survivor of the criminal law aspect of the old writ of trespass. PROSSER ET AL., supra, at 29. Aside from the dictum by Chief Justice Latham in Bunyan v. Jordan, 57 C.L.R. 1, 12 (1937) (Austl.), there is, to my knowledge, no trace of this doctrine in Commonwealth tort law. 
accompamied by material gain, the law of unjust enrichment allows recovery for material gam that is unaccompanied by material loss.

The possibility of gam without loss presents a well-known crux for the law of unjust enrichment. ${ }^{43}$ How can the defendant's gain be said to be "at the expense of" the plaintiff if the plaintiff is not worse off as a result of it? Suppose, for example, that the defendant profits through the unauthorized retention of machinery that its owner would not have used; ${ }^{44}$ or that the defendant commercially exploits a cave that opens only onto his property but runs beneath his neighbor's as well; ${ }^{45}$ or that a fiduciary profits from an opportumity that could not practically or legally be exploited by the principal; ${ }^{46}$ or that a soldier stationed abroad accepts bribes to let smugglers past checkpoints. ${ }^{47}$ In each of these cases, the defendant gams without inflictimg a correlative material loss on the plaintiff. The owner of the machmery can invoke no use that was frustrated; the neighbor has no way of exploiting a cave to which he has no access; the principal can point to no profit that the fiduciary intercepted; and the soldier's government cannot claim that it would have received the bribe pocketed by the soldier. Nonetheless, im all these situations, the law grants these plaintiffs restitution of what they never had and would not have received.

These examples of restitutionary liability rest on nornative rather than material correlativity. In each case the defendant has wrongfully infringed the plaintiff's right, either by using the plaintiff's property or by infringing the plaintiff's entitlement to loyalty or by abusing a position withm the plaintiff's service. Correlative to each of these rights is a duty owed by the defendants. Because

43. Restatement OF Restitution $\$ 1 \mathrm{cmt}$. e (1937); PETER Birks, AN INTROdUCTION to tHe LAW OF Restitution 12, 41 (1985); 1 GeOROE E. PALMER, THE LAW OF RESTITUTION 134 (1978); Smith, supra note 4, at 673-82.

44. Olwell v. Nye \& Nissen Co., 173 P.2d 652, 653-54 (Wash. 1946); Strand Elec. \& Eng'g Co. v. Brisford Entertainments, Ltd., [1952] 1 All E. R. 796, 798 (Eng. C.A.); see J. BEATSON, THE USE AND ABUSE OF UNJUST ENRICHMENT: ESSAYS ON THE LAW OF RESTTTUTION 230-34 (1991); E. Allan Farnsworth, Your Loss or My Gain? The Dilemma of the Disgorgement Principle in Breach of Contract, 94 YALE L.J. 1339, 1354-69 (1985); Daniel Friedmann, Restitution of Benefits Obtained Through the Appropriation of Property or Commission of a Wrong, 80 ColuM. L. Rev. 504, 508, 518-19 (1980).

45. Edwards v. Lee's Adm'r, 96 S.W.2d 1028, 1031-32 (Ky. Ct. App. 1936). For a recent discussion of this and similar cases, see John Glover, Restitutionary Principles in Tort: Wrongful User of Property and the Exemplary Measure of Damages, 18 MONASH U. L. REv. 169, 173-77 (1992).

46. Keech v. Sandford, 25 Eng. Rep. 223, 223-24 (1726).

47. Reading v. Attorney-General, 1951 App. Cas. 507, 511-12 (H.L.). 
the defendants' gains are the embodiments of the breaches of the duties, the plaintiffs are as entitled to the gains as they were to the duties. Because it is the excess over what the defendant ought to have in view of the breach of duty, the gain is also the correlative shortfall from what the plaintiff is entitled to as a matter of right. To paraphrase Aristotle, when the defendant's unjust enrichment is measured, it is called a gaim for one party and a loss for the other. ${ }^{48}$

\section{CONCLUSION}

Starting with the correlativity of gaim and loss in Aristotle's conception of corrective justice, I have suggested that these gains and losses are to be understood normatively (as relative to the parties' due) rather than materially (as relative to the parties' preexisting resources). The remedy due, in turn, depends on the reasons for regarding it as due. These reasons themselves must reflect in the correlativity of corrective justice by applying equally to both parties. The correlativity of right and duty in Kantian legal theory meets this requirement. The result is that the tortfeasor need not materially have gained nor the claimant of restitution materially have lost for liability to exeinplify corrective justice.

That the structure of the private law of reparation and restitution conforms to corrective justice should not be surprising. By requiring a single justification to apply correlatively to both litigants, corrective justice shows how private law can be a coherent normative phenomenon. Otherwise, the relationship between the parties would be torn apart $\mathrm{m}$ the tug of mutually independent reasons. As long as private law is a practice in which reasons and justifications matter, corrective justice will be the key to understanding it. And at the heart of corrective justice, linking the two parties, lies the correlativity of the normative categories of right and duty.

48. See supra text accompanying note 8 . 